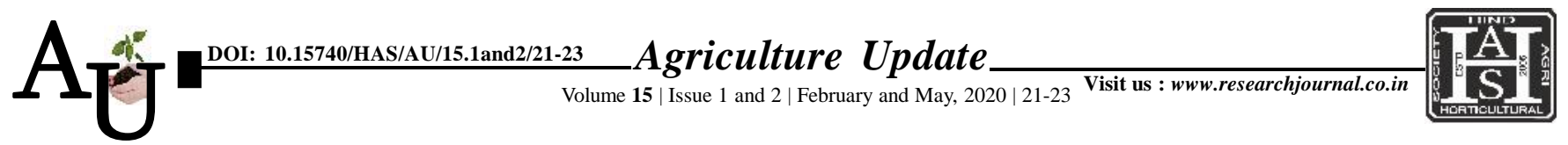

ISSN-0973-1520

\title{
Research Article: Constraints for organic farming practices in Bikaner district of Rajasthan
}

Dropati Saran and Madhu Sharma

Article Chronicle:

Received :

20.01.2020;

Revised :

26.03.2020;

Accepted :

04.04.2020

KeY Words :

Organic farming,

Rainfed farming,

Organic manures,

Marketing,

Constraints, Cost of

certification
SUMMARY : The present study was undertaken for studying constraints of organic farming practices in Bikaner district of Rajasthan. This district was selected purposively as it has large area under rainfed farming and mostly fertilizers and pesticides are not being used in this area. For the study 30 farmers practicing organic farming were selected. The results revealed that the important constraint faced by the farmers of study area were non-availability of sufficient organic manure, low productivity of organic farming, lack of selling outlets, marketing of organic farming produce is the main problem, certification facility is not available of organic farming, unawareness of organic farming, price of the organic products is the high and cost of certification organic farming is high. The study of constraints revealed that about 81.5 per cent farmers of the study area faced the problem about no availability of sufficient organic manure. The problem faced by the farmer is related to difficulty in adoptions of organic farming was worked out about 61.9 per cent. About 81.03 per cent farmers reported the problem of selling.

How to cite this article : Saran, Dropati and Sharma, Madhu (2020). Constraints for organic farming practices in Bikaner district of Rajasthan. Agric. Update, 15(1 and 2): 21-23; DOI : 10.15740/HAS/AU/15.1and2/21-23. Copyright@ 2020: Hind Agri-Horticultural Society.
Author for correspondence :

\section{Dropati Saran} Department of Agricultural Economics, College of Agriculture, Swami Keshwanand Rajasthan Agriculture University, Bikaner (Rajasthan) India Email: dropati.saran4@ gmail.com

See end of the article for authors' affiliations 